\title{
Sources of Economic Growth in 31 Sub-Sahara African Countries for the Period 1975-2008: A Growth Accounting Approach
}

\author{
Girma Zelleke $^{1} \&$ Abdulwahab Sraiheen ${ }^{1}$ \\ ${ }^{1}$ College of Business, Kutztown University of Pennsylvania, Kutztown, USA \\ Correspondence: Girma Zelleke, College of Business, Kutztown University of Pennsylvania, Kutztown, PA \\ 19530, USA. Tel: 1-610-944-0845. E-mail: Zelleke@kutztown.edu
}

Received: August 14, 2012

Accepted: August 31, $2012 \quad$ Online Published: September 5, 2012

doi:10.5539/ijef.v4n10p54

URL: http://dx.doi.org/10.5539/ijef.v4n10p54

\begin{abstract}
This paper examines the empirical validity of the Cobb- Douglas (CD) Model of Economic Growth for 31 Sub-Sahara African (SSA) countries. We made use of labor and capital shares of income coefficients estimated from aggregate production functions for both Kenya and South Africa. Using the estimated coefficients of factors share of income, we decomposed the sources of economic growth in the 31 SSAs as a group and, in each of the countries within the group for the periods 1975-2008 and, 1995-2008. Our findings indicate that from 1975-2008, about 68 percent of SSA's growth is accounted for by accumulation of physical capital, 28 percent by labor and, 3 percent by growth of total factor productivity. Among SSAs, the highest growth rate of GDP and, capital accumulation occurred during the period 1995-2008.
\end{abstract}

Keywords: measurement of economic growth, aggregate productivity, cross-country output convergence, Africa, comparative studies of countries

\section{Introduction}

The use of Growth Accounting approach to identify the sources of economic growth and, trends in labor productivity and, total factor productivity, came to prominence following the popular empirical studies by Edward Denison (1962). In one of his papers titled, "The Sources of Economic Growth in the United States and the Alternatives Before Us," (1962) and, in a series of other articles (1985) and five books that he authored while at the Brookings Institution, he decomposed the sources of economic growth for the United States economy from 1929-1982. Our objective in this paper is to use Denison's conceptual framework to gain some insight into the sources and determinants of economic growth and, labor productivity in a sample of 31 sub-Saharan African countries. The countries in our sample are heterogeneous in terms of their endowment of resources, ethnic composition, geographic size, political and, democratic institutions. The only common denominator among the group is similarity of standard of living as measured by per capita income. Our study differs from previous research in few fundamental ways. First, unlike previous research (Note 1) we made use of our own estimates of capital's and labor's shares of real GDP from two estimated regression equations one for Kenya, and a second for South Africa. Our estimated share of capital and labor income for SSA countries is very different from those used in past studies where labor and capital share of income are assumed to be the same as in industrialized countries. As most SSA countries are labor abundant and capital scarce, the wage rate and labor's share of income is much lower than in industrialized countries while, the opposite is true for capital's share of income. Second, we included a large number of countries 31 in our sample that covers a longer time period 1975-2008. Finally, we did not differentiate between oil and mineral exporting and/or importing countries because our main objective is to identify the various sources of growth and not to identify the reasons for differences of standard of living among countries.

Apart from empirical researchers interested in the area of long-term growth models, numerous other economists have produced a wide range of articles in an attempt to explain the causes for the slow growth of Africa since the first half of the 1970s. Growth in many African countries continued to decline from early 1970s to the middle of 1990s. The explanations for the slow growth of SSAs are numerous and most of them are convincing. Some of the explanations cited for the slow growth of SSA are listed in a survey article by (Collier and Gunning, 1999). The reasons cited for the slow growth of SSA are numerous and the list includes, overvaluation of currencies and restrictions of trade through quotas and tariffs, reliance on state ownership of enterprises, deterioration of the 
terms of trade, the prevalence of ethnic and linguistic fractionalization and its distortive effects on Macroeconomic Policies (Easterly and Levine, 1997), corruption of autocratic political leaders with no accountability and transparency, smallness of the size of countries which limits the provision of public services with economies of scale, the prevalence of tropical diseases and, lack of access to sea ports by land-locked countries (Sachs and Warner 1997), the absence of democratic institutions and that limits transparency and accountability by autocratic leaders.

As a result of mismanagement of economic policies and, poor institutional qualities, SSA countries were unable to attract foreign investment except into oil and minerals sectors or, to mobilize domestic saving for investment. With low rate of investment, the growth rates of capital accumulation and GDP stagnated until the middle of 1990s. Since 1995 however, due to recommendations for policy reform by the World Bank, the IMF and, the African Union, many African Countries are reforming their economic policies and institutional qualities. In a recent report by the World Bank on Africa's economic performance titled, "Country Policy and Institutional Assessment, CPIA", (2010), Cape Verdi, Tanzania, Uganda, Ghana, Burkina Faso, Senegal, Mali, and Rwanda are assigned high scores for reforming their economic policies, governance system and institutional qualities.

As indicated in Table 4 of our study, in most of these countries with high CPIA scores, the growth rates of physical capital accumulation and, GDP are much higher than in other SSA countries with low CPIA ratings. The countries with low CPIA scores include Zimbabwe, Comoros, Djibouti, Ivory Coast and a few others. In the countries with low CPIA scores, growth rate of capital accumulation and, GDP are also low.

The rest of the paper is organized as follows: Section 2 is a literature review of the Cobb-Douglas (CD) Model of growth and, derivation of the Growth Accounting Equation. Section 3 presents the sources of data, section 4 presents the statistical results and, Section 5 is a summary and some concluding remarks.

\section{Methodology}

\subsection{The Theoretical Model}

The basic model of our analysis is the Cobb-Douglas (CD) production function also known as, the neoclassical production function. The production function predicts that real GDP (Y) is determined by the stock of physical capital (K) net of depreciation, the number of employed workers (L) and, the productivity or efficiency (A) of both factors of production. The equation is specified as,

$$
Y=A\left(K^{\alpha} L^{\beta}\right)
$$

With $\alpha$ and $\beta$ denoting the elasticities of output with respect to capital and labor respectively or, the share of GDP received by capital owners and by workers. (Note 2) In empirical studies, the parameters $\alpha$ and $\beta$ are estimated by transforming equation (1) into double log econometric model as in equation (2). It is assumed that the production function in equation (1) exhibit constant returns to scale, i.e., $\beta=1-\alpha$.

$$
\ln (Y)=\ln (A)+\alpha \ln (K)+\beta \ln (L)+\varepsilon
$$

Where $\ln$ is the natural $\log$ and $\varepsilon$ is an additive error term. As discussed in footnote 2, an alternative model for estimating $\alpha$ and $\beta$ is of the form below:

$$
\ln (Y)=\ln (A)+\alpha \ln (1-W s)+\beta \ln (W s)+\varepsilon
$$

Where $\mathrm{Y}$ is real GDP, Ws is income share received by labor, and (1 - Ws) is share of income received by capital owners. Substituting the estimated values of $\beta$ and $\alpha$ in equation (1), the Total Factor Productivity (TFP) variable (A), also known as Solow's Residual can be computed as (A) $=Y / K^{\alpha} L^{\beta}$. The time derivative of CD Production function will yield what is known in growth literature as, Growth Accounting Equation. The Growth Accounting Equation is often used in major empirical studies (Denison, 1962, 1979, 1985), to decompose the sources of GDP growth that is accounted by growth rate of the two factors of production (labor and capital) and, by growth rate of total factor productivity (TFP). The growth accounting equation is of the form,

$$
\dot{Y}=\dot{a}+\alpha \dot{K}+\beta \dot{L}=\frac{\Delta Y}{Y}=\frac{\Delta A}{A}+\alpha \frac{\Delta K}{K}+\beta \frac{\Delta L}{L}
$$

Subtracting $\dot{L}=\Delta L / L$ from both sides of the equation, and substituting (1- $\alpha$ ) for $\beta$, equation (4) can be written as equation (5) below. In growth literature, equation (5) is a measure of the average productivity of labor. (Abel, Bernanke, and Croushore, 2008).

$$
\dot{Y}-\dot{L}=\dot{a}+\alpha(\dot{K}-\dot{L})=\frac{\Delta Y}{Y}-\frac{\Delta L}{L}=\frac{\Delta A}{A}+\alpha\left(\frac{\Delta K}{K}-\frac{\Delta L}{L}\right)
$$


Equation (5) states that the growth rate of productivity of labor is determined by the growth rate of total factor productivity or technology $(\dot{a})$ and, the growth rate of capital to labor ratio, or $\alpha(\dot{K}-\dot{L})$.

The Human Capital Augmented version of Cobb-Dog Production function is specified as,

$$
\mathrm{Y}=\mathrm{A}\left(\mathrm{K}^{\alpha}(\mathrm{LH})^{\beta}\right.
$$

Where $\mathrm{H}$ denotes human capital embodied in labor, $\alpha$ and $\beta$ denote capital and labor's share of income respectively.

Defining the total income share of labor $(\mathrm{LH})^{\beta}$ as consisting of income from raw labor $\left(\mathrm{L}^{\theta}\right)$ with zero education, $\left(\mathrm{H}^{\lambda}\right)$, as the return to human capital embodied in labor, and $\mathrm{K}^{\alpha}$ as the share of capital income, the human- capital augmented version of CD Production function can be stated as,

$$
\mathrm{Y}=\mathrm{A}\left(K^{\alpha} L^{\theta} H^{\lambda}\right)
$$

Under the assumption of constant returns to scale, $(\alpha+\theta+\lambda)=1$ and, $(\lambda+\theta)=\beta$.

Equation (6) can be estimated by transforming it into a natural $\log$ form as in below.

$$
\ln (\mathrm{Y})=\ln (\mathrm{A})+\alpha \ln (\mathrm{K})+\theta \ln (\mathrm{L})+\lambda \ln (\mathrm{H})+\varepsilon
$$

In this paper, we will focus on estimating equation 3 , and perform the calculations as in equations 4 and 5 , and will tackle the human capital augmented version of the model in a forthcoming paper.

\section{Sources of Data and Samples}

Our sample includes 31 SSA countries with data for each country covering the period from 1975-2008. (Note 3) The primary source of data is the Extended Penn World Tables, Version 4.0 (Note 4), which includes data on additional variables that are not reported in PWT Version7 (Heston, summers, and Aten, 2011) data.

Unlike previous studies Mankiw, Weil and Romer (1992); Jones and Hall (1999) which exclude oil and mineral exporting countries from their sample, our sample includes all 31 countries in Sub-Sahara Africa region, irrespective of the product composition of their export. Due to the relative abundance and a high export share of natural resource intensive products, SSA countries such as, South Africa, Botswana, Equatorial Guinea, Angola, Nigeria have been able to attract a substantial amount of foreign capital and a subsequent accumulation of the stock of physical capital. Since the stock of physical capital is one of the major sources of economic growth, we didn't think it would be appropriate to exclude mineral and oil exporting countries from our sample.

A complete set of data on wage share of real GDP for only Kenya, South Africa and, Botswana is reported in (EPWT.V.4.0, 2011). For most other SSAs, wage share data is either unavailable or, coverage is limited to no more than 10 years. Among the countries for which data on wage share of real GDP is reported, one can observe that among OECD countries the ratio of wage income to GDP lies within a range of 55-66 percent but, for low-income SSA countries the ratio drops to a range that is as low as 15 - 40 percent. As South Africa's income per person is much higher than in the rest of SSA countries, the ratio of wage income to GDP is about 55 percent The data on wage share of real GDP as reported in (EPWT. V.4.0, 2011) indicates that labor's share of income in low-income countries is much lower than it is in high-income countries.

In an estimate of labor's share of income using the Cobb-Douglas Model, other studies, (Bernanke \& Gurkaynak, 2002) have reported that the average value of the estimated coefficients of wage share of real GDP in a sample of 54 (OECD and low-income) countries, is 0.65 or, 65 percent of GDP. However, among the 54 countries in the sample, the authors report that the estimated coefficients of wage share of income for five SSA countries included in their sample are 0.22 for Burundi, 0.38 for Congo, 0.43 for Ivory Coast, 0.48 for Zambia and, 0.59 for S. Africa. This implies that the average value of the estimated coefficients for the four low-income SSAs (Burundi, Ivory Coast, Congo and Zambia) is only 0.3775.

Since the sample of countries in our study consists of only SSAs, we have chosen not to use a wage share to GDP coefficient of 0.65 , as has been the standard practice in most other empirical studies (Mankiw, Jones and Hall, Bernanke) of the neoclassical or Solow's Growth model. Instead of assuming labor's share of income to be 0.65 , we made our own estimate of labor's share of income for Kenya and for South Africa from historical data reported in (EPWT.V.4, 2011). The coefficients are estimated using ordinary least squares regression method with White Heteroscedasticity Consistent Standard Errors results are reported in the next section.

Since Kenya's standard of living and structure of economic development is similar to most other low-income SSAs, we made the judgment that our estimated coefficient of labor's share of income obtained from Kenya's wage share data can be used as representative of all other low-income SSAs except for South Africa. Interestingly, our estimated coefficient for Kenya's wage share of GDP, turned-out to be the same as the average 
estimate 0f 0.37 reported in Bernanke's study for four low-income SSA countries. As South Africa is a high income country, our estimated wage share coefficient for South Africa is 0.60 which turned out to be the same as Bernanke's estimate of 0.59 .

\section{Results of Statistical Estimates}

As mentioned in Section 3, we made our own estimate of labors and capital's share of income for Kenya and, for South Africa and the results are as reported in Table 1. Our choice of Kenya to be the representative country of all other SSAs, is influenced by our consideration of factors such as, Kenya's long-standing experience with the free market system where factor price distortions are at a minimum, its macroeconomic and political stability relative to most other SSAs, the availability of a complete set of data on all variables that are of interest to the current study and, the similarity of Kenya's standard of living with other low-income SSAs.

The estimated income share of labor and capital for Kenya and South Africa are reported in Table (1). The dependent variable is the natural $\log$ of real GDP (Y) in 2005 purchasing power parity (chain index). The two independent variables are natural $\log$ of their estimate of net fixed standardized capital stock (K) in 2005 purchasing power parity, and the natural $\log$ of number of employed workers $(\mathrm{N})$. These estimated functions provided the output elasticities with respect to both capital $(\alpha)$ and labor $(\beta)$.

As indicated in the table, the wage share of GDP $(\beta)$ for Kenya is 0.37 and, capital's share $(\alpha)$ is 0.63 . Both coefficients are statistically significant at the 1 percent level of significance as evidenced by the low values of

SEE relative to the estimated value of the coefficients.

Table 1. Estimated Aggregate Production Function for Kenya and South Africa: Dependent variable: natural log of real GDP $(\operatorname{Ln}(Y))$

\begin{tabular}{lll}
\hline Variable & Kenya $^{\dagger}$ & South Africa \\
\hline Constant $\beta_{0}$ & $0.7048^{*}$ & $\begin{array}{l}5.8703^{*} \\
(0.6172)\end{array}$ \\
\hline Ln Capital $(\alpha)$ & $\begin{array}{l}0.6261^{*} \\
(0.00258)\end{array}$ & $\begin{array}{l}0.38599^{*} \\
(0,03797)\end{array}$ \\
\hline Ln Labor $(\beta)$ & $0.3721^{*}$ & $0.61218^{*}$ \\
& $(0.00271)$ & $(0.0341)$ \\
\hline Adjusted $-\mathrm{R}^{2}$ & 1.0000 & 0.9833 \\
\hline F-Ratio & 1551013 & $1268.25^{*}$ \\
\hline $\boldsymbol{n}$ & 39 & 44 \\
\hline
\end{tabular}

$\dagger$ Kenya's production function was estimated using equation (3)

All coefficients are significant at the 99.99percent

$\mathrm{Ln}=$ Natural $\log$

Standard errors in parentheses

Once again, it is interesting to note that the estimated values of our coefficients for Kenya are just about the same as the average value of the estimates obtained in (Bernanke \& Gurkaynak, 2002) study for the four low-income SSA countries.

On the other hand, the estimated coefficient of labor's share of income for South Africa is much higher than it is for Kenya. As reported in Table 1, the coefficient of labor's share of income is 0.61 and, capitals share of income is 0.39. Our estimates of $(\alpha)$ and $(\beta)$ values for South Africa, are just about the same as the estimates in Bernanke's study. In spite of the stark differences in labor's and capital's share of income between low-income and high-income countries, the conventional practice applied in almost all previous empirical studies of growth models, (Mankiw, Romer and Weil, 1992). Bosworth and Collins, Jones and Hall, Bernanke is based on the assumption that the value of $(\alpha)$ for all countries is 0.35 and the value of $\beta$ is 0.65 . To the extent that the sample of countries included in most of the previous studies largely consists of high-income countries, the assumption of a high value of $\beta$ and, a low value of $\alpha$ may be appropriate (Note 5). However, in SSA countries, where the majority of the labor force is engaged in the informal urban sector and, in subsistence agriculture with little or no physical and, human capital, the productivity and contribution of labor to output growth is very low. In Angola 
for example, oil production which is a capital intensive activity accounts for about 85 percent of GDP and, the subsistence agricultural sector which provides the main livelihood for most of the people accounts for about 10 percent of GDP (CIA World Fact book, 2012). Although Angola's case of natural resource endowment is similar to a few other SSA countries, it is not typical of other resource poor SSAs. However, almost all SSA countries except South Africa, share a common characteristic of low productivity of labor and, low wage share of GDP. In view of this consideration, we decided to use our own statistical estimate of Kenya's wage share of GDP and capital's share of income, as representative of all other low-income SSA countries, with South Africa as an exception.

Using 5 years panel data for the period 1975-2008, and an $\alpha$ value of 0.63 and, a $\beta$ value of 0.37 for 30 low-income SSA countries excluding South Africa, we estimated the Growth Accounting Equation (4) to identify the sources of economic growth in all and in each of the 30 countries. The decomposition of the sources of economic growth for South Africa, is based on its own estimate of $\alpha=0.61$ and $\beta=0.0 .39$. Table 2 in appendix A provides variable names and definitions and units of measurement.

\subsection{Sources of Economic Growth in 31 SSA Countries}

Table 3 provides a summary of the sources of growth for all 31 countries taken as a group for the period 19752008 and, Tables 4A, 4B present similar estimates for each of the 31 SSAs separately. As can be seen from these tables, growth varied between periods and also between countries.

Table 3. Sources of Economic Growth for 31 Sub-Sahara African Countries for the period $1975-2008$ ( $\mathrm{n}=$ 1067)

\begin{tabular}{|c|c|c|c|c|c|c|c|}
\hline Period & $\dot{\boldsymbol{Y}}$ & $\dot{\boldsymbol{L}}$ & $\dot{\boldsymbol{K}}$ & $C L$ & $C K$ & $\dot{\boldsymbol{a}}$ & $\dot{y}$ \\
\hline $1975-1979$ & 2.74 & 2.33 & 5.33 & 0.88 & 3.32 & -1.48 & 0.40 \\
\hline 1980-1984 & 2.68 & 3.01 & 2.94 & 1.14 & 1.82 & -0.29 & -0.33 \\
\hline 1985-1989 & 3.89 & 2.79 & 1.70 & 1.06 & 1.08 & 1.79 & 1.10 \\
\hline 1990-1994 & 0.87 & 3.11 & 3.06 & 1.18 & 1.94 & -2.21 & -2.24 \\
\hline 1995-1999 & 5.67 & 2.58 & 4.40 & 0.97 & 2.76 & 1.95 & 3.09 \\
\hline $2000-2004$ & 4.79 & 3.20 & 3.55 & 1.20 & 2.21 & 1.37 & 1.59 \\
\hline 2005-2008 & 5.76 & 2.77 & 8.35 & 1.04 & 5.21 & -0.52 & 2.99 \\
\hline Average $75-08, n=1067$ & 3.74 & 2.83 & 4.06 & 1.07 & 2.54 & 0.13 & 0.90 \\
\hline Average 95-08, $n=434$ & 5.74 & 2.95 & 5.48 & 1.11 & 3.42 & 1.21 & 2.80 \\
\hline
\end{tabular}

The calculations of the contributions of factors of production are based on the estimated production function of Kenya and South Africa $\left(Y=A K^{\alpha} L \beta\right)$ with $\alpha=0.63$ for Kenya and 0.39 for South Africa.

As presented in Table 3, for the group of 31 countries, the GDP has increased at annual average rate of 3.74 percent during the period 1975-2008. Most of this growth occurred after 1995, a period that coincides with the collapse of the former Soviet Union in 1991. Following the collapse of the socialist system in the former Soviet Union, many SSAs have adopted a free market system, privatized state-owned enterprises and, liberalized restrictions on trade, in part due to reform measures required by International lending institutions such as, the IMF and the World Bank. It is also possible that the strong recovery that took place in industrialized countries and in emerging economies, from 1995 until the beginning of the Financial Crises of 2007, may have contributed to growth of demand for primary export goods originating from SSA countries that led to a subsequent increase in the growth rate of GDP. From 1995 to 2008, SSAs recorded an average growth rate of GDP that was as high as 5.4 percent.

The GDP growth rate is closely correlated with growth rate of physical capital accumulation. As the GDP growth rate accelerated from 2.55percent before 1995, to 5.74 percent after 1995, the growth rate of physical capital accumulation also accelerated from 2.0 percent before 1995, to 5.48 percent after 1995. Overall, accumulation of capital accounts for a substantial portion of SSAs economic growth. For the period from 19752008, Capital accumulation accounts for 68 percent of the growth rate of GDP of 3.74 percent and, labor accounts for 28.6 percent of GDP growth and, Total Factor Productivity (TFP) growth accounts for a meager 3.2 percent of GDP growth. From the figures, reported in Table 2, it can be said that during the period 1975-2008, growth in total factors (capital and labor) of production, accounted for 97 percent of the annual growth rate of GDP of 3.74 percent and, Total Factor Productivity growth accounts for only 3 percent of the growth of output. 
The last column in Table 3 indicates the growth rate of labor productivity. As stated in equation (5) and repeated below, the growth rate of labor productivity shown in column (7), can exceed, the growth rate of Total Factor Productivity shown in column (6), only if the growth rate of capital/labor ratio, is positive. If the growth rate of capital/labor ratio zero, Growth rate of total factor productivity will be equal to growth rate of labor productivity.

$$
\dot{Y}-\dot{L}=\dot{a}+\alpha(\dot{K}-\dot{L})=\frac{\Delta Y}{Y}-\frac{\Delta L}{L}=\frac{\Delta A}{A}+\alpha\left(\frac{\Delta K}{K}-\frac{\Delta L}{L}\right)
$$

For the sample period 1975-2008, labor productivity increased at an annual rate of 0.9 percent but, Total Factor Productivity (TFP) increased at an annual rate of only 0.13 percent. The difference between the growth rate of labor productivity $(\dot{Y}-\dot{L})$, that exceeds the growth rate of Total Factor productivity $(\dot{a})$ if positive, is a measure of an increase in labor productivity that is caused by an increase in the growth rate of capital/labor ratio.

$$
(\dot{Y}-\dot{L})-\dot{a}=\alpha(\dot{K}-\dot{L})
$$

The Growth of $\alpha(\dot{K}-\dot{L})$, appears to be more pronounced for the period after 1995, a period in which GDP growth and capital growth are much higher than the period before 1995. For all other five-year periods before 1995, except 1975-1979, the growth rate of labor productivity is less than the growth rate of Total Factor Productivity. In this case, the capital to labor ratio must be decreasing and $(\dot{K}-\dot{L})$ will take a negative value. A closer look at the growth rates of capital and labor for each of the 5 year periods, from 1975-1995 presented in Table (3), indicates that growth rate of the labor force $\dot{L}$, was higher than the growth rate of capital $(\dot{K})$ for all 5 year periods except in 1975-1979.

For all 5 year periods after 1995, the growth of capital exceeded the growth of labor and consequently the capital- labor ratio has been positive and greater than zero. As long as growth rate of capital exceeds the growth of labor, i.e., $(\dot{K}-\dot{L})$ is positive, the growth rate of labor productivity $\{\dot{a}+\alpha(\dot{K}-\dot{L})\}$, will exceed the growth rate of Total Factor Productivity $(\dot{a})$ that can result from technological improvement or efficient use of both factors of production. Since 1995, it appears that most SSA countries in particular those who are assigned high CPIA scores by the World Bank for implementing structural and policy reform measures, (Rwanda, Uganda, Tanzania, Ghana and Burkina Faso) have achieved a higher growth rates of GDP, capital accumulation and growth rate of labor productivity. For SSA countries as a whole, Growth rate of GDP has increased from 3.74 percent during (1975-2008) period, to 5.74 percent in (1995-2008). During the same time period, the growth rate of capital accumulation has increased from 4.06 to 5.48 percent and, the growth rate of labor productivity increased from 0.9 to 2.8 percent. The increase in labor productivity from 0.9 percent during (1975-2008) to, 2.80 percent during (1995-2008) period, is caused by an increase of capital per worker ratio and, by a simultaneous increase of total factor productivity $(\dot{a})$.The rise in total factor productivity from 0.13 to 1.21 percent, could have resulted from economic and institutional reform measures adopted by most SSAs since 1995, or it could be due increased use of the internet. Understanding the exact causes of the rise in total factor productivity would be an interesting topic for future research. If the post 1995 trend improvement in all indicators except, growth of the labor force is maintained into the future, SSA countries have a good prospect of reversing the decline of economic activities and, standard of living witnessed in the 1970s and 1980s.

Table (4A \&4B) in Appendix A shows estimates of Growth Accounting Equation for each of the 31 SSA countries for the Period (1975-2008) and for the period (1995-2008) respectively.

In Tables (4A \& 4B), the countries are ranked according to growth rates of GDP in descending order for the two sample periods (1975-2008) and (1995-2008). In most of these countries, with the exception of those with ongoing civil war such as, Zimbabwe, Democratic Republic of Congo, Central African Republic, Sierra Leone, Djibouti, Ivory Coast, and Burundi, there is a noticeable improvement in growth rates of GDP, capital accumulation, total factor productivity and, labor productivity during the period from 1995-2008 compared to the earlier period (1975-2008). In the conflict countries, most of the growth indicators except growth rate of labor force are either low or negative. In particular, growth rates of total factor productivity and, labor productivity among conflict countries, continue to be negative. Oil and precious mineral exporting countries such as Equatorial Guinea, Angola, Chad, Zambia and, Botswana have the highest growth rate of capital accumulation possibly due to, a high rate of Foreign Direct Investment in mining sector.

Table 5 in appendix A contains detailed estimate of the sources of growth for each of the 31 SSA countries for each five year period from (1975-2008).

\section{Summary and Conclusions}

Previous empirical studies on growth theories and growth accounting estimates are based under the assumption that labor's share of income is 0.65 and, capital's share is 0.35 in all countries irrespective of differences in the 
level of per capita of countries. The assumption of a standardized factor share of income in empirical studies would be a valid assumption only if the sample of countries included in the study consists of countries that have a similar level of per capita income. However, a casual observation of a recently published data on wage share of income used in our study, indicates that labor's share of income in low income countries is consistently lower in low income countries than it is in high income countries. We believe, that the assumption and use of a homogenous factor share income for all countries we believe, could lead the researcher to arrive at a biased and incorrect conclusion.

In recognition of the sensitivity of all growth theories to the parameter vales of labor and capital share of income, we made our own estimates of factor income share coefficients Kenya and, South Africa. As expected, our regression estimate of labor's share of income is 0.37 for Kenya and, 0.59 for South Africa. Considering that Kenya's standard of living and, level of per capita income is similar to most SSA countries except South Africa, we used Kenya's income share parameters for all other SSAs except for South Africa to decompose the sources of GDP growth in 31 SSAs as a group and, in each country within the group for two time periods 1975-2008 and, 1995-2008.

It is important to note here that despite of the high average growth rate for the sample periods, growth rates fluctuated widely between countries and within each country for the sample periods. It is also clear that growth rates have accelerated for majority of the 31 SSA's during the 1995-2008 period.

Our findings indicate capital accumulation is the most important source of economic growth. For the period (1975-2008), about 69 percent of SSAs GDP growth is accounted by growth of capital accumulation, 28 percent by growth of labor force and, 3 percent by TFA. Since we did not decompose human capital embodied in raw labor, our measure of labor's contribution to GDP growth could be exaggerated. During the same period, labor productivity increased at an average rate of 0.90 mostly due to an increase of capital/labor ratio rather than to growth of technical efficiency or TFP.

A few years after the end of the former Soviet Union, a number of SSA countries reformed their economic and political systems of governance by liberalizing trade regimes, privatizing state owned enterprises, revising investment laws and by improving the institutional quality of governance.

Among the countries that implemented economic and political reform from 1995 until 2008, growth rates of GDP, capital accumulation, total factor productivity (TFP) and, labor productivity have increased significantly compared to the period from (1975-2008). However, in other SSA countries where reform measures are not implemented due to political instability and ongoing civil war ((Zimbabwe, Sierra Leone, Ivory Coast, Democratic Republic of Congo, Comoros, and Djibouti) growth of GDP is close to zero or negative. In such countries TFP and labor productivity growth rates are negative. If Africa continues to reform its economic and political systems, it will remain to be magnet for foreign investment and accumulation of capital which has remained to be a limiting factor of SSAs economic growth.

\section{References}

Abel, Andrew, Ben S. Bernanke, \& Dean Croushore. (2008). Macroeconomics (Sixth Edition). Boston: Pearson Addison Wesley.

Bernanke, Ben, \& Refet S. Gurkaynak. (2002). Is Growth Exogenous? Taking Mankiw, Romer, and Weil Seriously. NBER Macroeconomics Annual 2001, 16(16). Ed. Ben and Kenneth Rogoff Bernanke. Washington: MIT Press, January.

Bosworth, Barry, \& Susan Collins. (2008). Accounring for Growth: Comparing China and India, 22. Winter.

Central Intellegence Agency. (2012) World Factbook. June 5.

Cohen, Daniel, \& Marcelo Soto. (2002). Why Are Some Countries So Poor? Another Look at the Evidence and a Message of Hope. Paris: OECD Development Centre. http://dx.doi.org/10.1787/205835882383

Collier, Paul, \& Jan Willem Gunning. (1999). Explaining African Economic Performance, 37.

Collins, Susan, \& Barry Bosworth. (1996). Economic Growth in East Asia: Accumulation versus Assimilation. Brookings Papers on Economic Activity, 2, 135-191.

Denison, Edward Fulton. (1979). Accounting for Slower Economic Growth: The United States in the 70's. Washington, DC: The Brooking Institute.

Denison, Edward. (1962). The Sources of Economic Growth in the United States and the Alternatives Before US. The Brookings Institute. Washington, D. C. 
Easterly, W., \& R. Levine. (1997). Africa's Growth Tragedy: Policies and Ethnic Divisions. Quarterly Journal of Economics, 112(4), 1203-1250.

Easterly, William, \& Ross Levine. (1998). Troubles with the Neighbours: Africa's Problem, Africa's Opportunity. Journal of African Economies, 7(1), 120-142. http://dx.doi.org/10.1093/oxfordjournals.jae.a020941

Hall, R. E., \& C. I Jones. (1999). Why Do Some Countries Produce So Much More Output Per Worker Than Others? The Quarterly Journal of Economics, 1(114), 83-116. http://dx.doi.org/10.1162/003355399555954

Heston, Allen, Robert Summers, \& Bettina Aten. Penn World Tables. Center for International Comparisons of Production, Income and Prices at the University of Pennsylvania. Philadelphia, n.d.

Mankiw, N. Gregory, David Romer, \& David Weil. (1992). A Contribution to the Empirics of Economic Growth. The Quarterly Journal of Economics, 107(2), 407-437. http://dx.doi.org/10.2307/2118477

Marquetti, Adalmir, \& Duncan Foley. (2011). Extended Penn World Tables - EPWT Version 4.0. New York, August.

Ndulu, Benno, \& Stephen A. O'Connell. (2003). Revised Collins/Bosworth Growth Accounting Decompositions. March .

O'Connell, S., \& B. Ndulu. (2012). Africa's growth experience: a focus on sources of growth. May 8.

Sachs, Jeffrey, \& Andrew Warner. (1997). Sources of Slow Growth in African Economies. Journal of African Economies, 6(3), 335-376. http://dx.doi.org/10.1093/oxfordjournals.jae.a020932

Stone, Richard. (1980). Whittling Away at the Residual: Some Thoughts on Denison's Growth Accounting. Journal of Economic Literature, XVIII, 1539-1543.

The Empirics of Growth: An Update. (2003). Washington, D.C.: Brookings Institution, September.

World Bank. (2012). Country Policy and Institutional Assessment, CPIA. 10 June.

\section{Notes}

Note 1. For example Mankiw, Romer, and Weil (1992), Nadulu and O'Conner (2000, 2003), Bosworth and Collins (2003) and others.

Note 2. The partial derivative of expression (1) with respect to Labor (L), $\frac{\partial Y}{\partial L}=\beta \mathrm{AK}^{\alpha} \mathrm{L}^{\beta-1}=\beta(\mathrm{Y} / \mathrm{L})$ and solving for $\beta$, yields $\beta=\frac{\partial Y}{\partial L} * \frac{L}{Y}$ which is, elasticity of output with respect to labor. Under the assumption of competitive labor market where the real wage of labor $(\mathrm{w})=$ Marginal product of labor, $\beta=(\mathrm{w} \times \mathrm{L}) / \mathrm{Y}$ which is, the wage share of GDP.

Note 3. Except for Angola and Djibouti, the data is for 1984-2008.

Note 4. Extended Penn Tables (EPWT) version 4.0, August, 2011, by Adalmir Marquetti and Duncan Foley.

Note 5. In a separate regression for all 31 Sub-Sahara countries, using panel data $(n=1067)$ not reported here, our estimated output elasticity with respect to labor is 0.32 and that of capital is 0.68 . It is more evidence to support the use of different labor and capital shares than those used for advanced countries.

\section{Appendix A}


Table 2. Variables Used in the Study and their Definitions

\begin{tabular}{|c|c|c|}
\hline Variable & Definition & Units \\
\hline$\dot{\boldsymbol{Y}}$ & $\begin{array}{l}\text { Growth rate of real GDP. It is calculated as } \Delta Y / Y \text {, where } \mathrm{Y} \text { is GDP in } 2005 \text { purchasing power parity as reported in the } \\
\text { Extended Penn Tables Version 4.0, (August 2011) }\end{array}$ & percent \\
\hline$\dot{L}$ & $\begin{array}{l}\text { Growth rate of labor. It is calculated as } \Delta N / N \text {, where } \mathrm{N} \text { is number of employed workers as reported in the Extended } \\
\text { Penn Tables Version 4.0. (August 2011) }\end{array}$ & Percent \\
\hline$\dot{\boldsymbol{K}}$ & $\begin{array}{l}\text { Growth rate of capital. It is calculated as } \Delta K / K \text {; where } \mathrm{K} \text { is the estimated net fixed standardized capital stock (K) in } \\
2005 \text { purchasing power parity as reported in the Extended Penn Tables Version 4.0. (August, 2011) }\end{array}$ & Percent \\
\hline$\dot{y}$ & $\begin{array}{l}\text { Growth rate of labor productivity. It is calculated as } \dot{Y}-\dot{L}=\Delta Y / Y-\Delta N / N \text { from the data in the Extended Penn } \\
\text { Tables Version 4.0. }\end{array}$ & Percent \\
\hline CK & $\begin{array}{l}\text { Contribution of physical capital }=\alpha * \text { (growth rate of physical capital, }(\dot{\boldsymbol{K}}) \text {. Where } \alpha \text { is } 0.63 \text { for all Sub-Sahara } \\
\text { countries in the sample excluding South Africa. The } 0.63 \text { is capital share of real GDP from the estimated aggregate } \\
\text { production function of Kenya as reported in table } 1 \text {. For South Africa only } \alpha \text { is } 0.39 \text {. }\end{array}$ & percent \\
\hline$C L$ & $\begin{array}{l}\text { Contribution of labor }=(1-\alpha) *(\text { growth rate in labor } \dot{\boldsymbol{L}}) . \text { Where }(1-\alpha)=0.37 \text { for all the countries in the sample except } \\
\text { South Africa. For South Africa, labor share is } 0.61 \text { as estimated in table } 1 .\end{array}$ & percent \\
\hline$\dot{a}$ & Total Factor Productivity TFP (residual) $=\dot{Y}-C K-C L$ or $T F P=\dot{Y}-\alpha(\dot{K}-\dot{L})$ & percent \\
\hline
\end{tabular}

Table 4A. Average Annual Growth Rates of Real Output(Y), Labor( $\dot{\mathrm{L}})$, Capital(K), Labor Productivity(y), Sources of Economic Growth and Total Factor Productivity (TFP) for 31 Sub-Saharan Countries for the Period 1975-2008*

\begin{tabular}{|c|c|c|c|c|c|c|c|}
\hline Country & $\dot{Y}$ & $\dot{L}$ & $\dot{\boldsymbol{K}}$ & $C L$ & CK & TFP & $\dot{y}$ \\
\hline Equatorial Guinea & 15.47 & 3.01 & 19.96 & 1.11 & 12.57 & 1.78 & 12.46 \\
\hline Botswana & 8.50 & 3.93 & 9.01 & 1.46 & 5.68 & 1.37 & 4.57 \\
\hline Angola & 6.45 & 2.29 & 3.52 & 0.85 & 2.21 & 3.39 & 4.16 \\
\hline Mauritius & 5.38 & 1.99 & 5.21 & 0.74 & 3.28 & 1.36 & 3.39 \\
\hline Cape Verde & 5.30 & 2.46 & 4.95 & 0.91 & 3.12 & 1.27 & 2.84 \\
\hline Mali & 5.02 & 2.12 & 4.50 & 0.78 & 2.84 & 1.40 & 2.90 \\
\hline Rwanda & 4.94 & 2.99 & 5.92 & 1.11 & 3.73 & 0.11 & 1.95 \\
\hline Tanzania & 4.63 & 2.81 & 4.82 & 1.04 & 3.04 & 0.55 & 1.82 \\
\hline Uganda & 4.53 & 3.02 & 5.00 & 1.12 & 3.15 & 0.27 & 1.51 \\
\hline Chad & 4.30 & 2.44 & 7.63 & 0.90 & 4.81 & -1.41 & 1.86 \\
\hline Burkina Faso & 4.18 & 2.88 & 5.19 & 1.07 & 3.27 & -0.16 & 1.30 \\
\hline Ethiopia & 4.06 & 2.93 & 3.11 & 1.09 & 1.96 & 1.01 & 1.12 \\
\hline Congo Republic & 3.97 & 3.11 & 5.36 & 1.15 & 3.38 & -0.56 & 0.86 \\
\hline Mozambique & 3.74 & 2.08 & 4.68 & 0.77 & 2.95 & 0.02 & 1.66 \\
\hline Cameroon & 3.64 & 2.82 & 3.79 & 1.04 & 2.39 & 0.21 & 0.82 \\
\hline Kenya & 3.52 & 3.57 & 3.26 & 1.32 & 2.05 & 0.14 & -0.06 \\
\hline Senegal & 3.46 & 2.71 & 5.57 & 1.00 & 3.51 & -1.05 & 0.75 \\
\hline Ghana & 3.36 & 3.09 & 1.64 & 1.14 & 1.03 & 1.18 & 0.27 \\
\hline Burundi & 3.12 & 3.06 & 4.82 & 1.13 & 3.04 & -1.05 & 0.05 \\
\hline South Africa & 3.09 & 3.01 & 2.46 & 1.84 & 0.96 & 0.29 & 0.07 \\
\hline Ivory Coast & 2.98 & 3.48 & 1.42 & 1.29 & 0.90 & 0.80 & -0.50 \\
\hline Nigeria & 2.92 & 2.55 & 3.15 & 0.94 & 1.99 & -0.01 & 0.37 \\
\hline Zambia & 2.86 & 2.91 & 1.45 & 1.08 & 0.91 & 0.87 & -0.05 \\
\hline Malawi & 2.69 & 2.74 & 0.65 & 1.02 & 0.41 & 1.26 & -0.06 \\
\hline Madagascar & 2.61 & 3.11 & 2.36 & 1.15 & 1.49 & -0.03 & -0.50 \\
\hline Comoros & 2.08 & 3.57 & 0.07 & 1.32 & 0.04 & 0.71 & -1.50 \\
\hline Djibouti & 1.49 & 5.90 & 3.73 & 2.18 & 2.35 & -3.04 & -4.41 \\
\hline Sierra Leone & 1.41 & 1.36 & 4.98 & 0.50 & 3.14 & -2.23 & 0.05 \\
\hline Central African Republic. & 1.20 & 2.44 & -0.06 & 0.90 & -0.04 & 0.34 & -1.24 \\
\hline Congo Democratic Republic & -0.44 & 2.87 & 0.26 & 1.06 & 0.16 & -1.67 & -3.32 \\
\hline Zimbabwe & -0.65 & 1.98 & 0.45 & 0.73 & 0.28 & -1.66 & -2.62 \\
\hline Average & 3.74 & 2.83 & 4.06 & 1.07 & 2.54 & 0.12 & 0.90 \\
\hline
\end{tabular}

*Angola and Djibouti data are from 1984-2008. 
$T F P=\frac{\Delta A}{A}=\frac{\Delta Y}{Y}-\alpha\left[\frac{\Delta K}{K}-\frac{\Delta N}{N}\right]$; Where $\mathrm{Y}$ is Real GDP in 2005 prices, $\mathrm{K}$ is net capital stock, $\mathrm{N}$ is number of working

population and $\alpha$ is elasticity of output with respect to capital and estimated for Kenya to equal 0.63 and South Africa of 0.39 aggregate Cobb-Douglas production functions. Labor productivity $(\dot{y})=\frac{\Delta Y}{Y}-\frac{\Delta N}{N}=\frac{\Delta A}{A}+\alpha\left[\frac{\Delta K}{K}-\frac{\Delta N}{N}\right]$

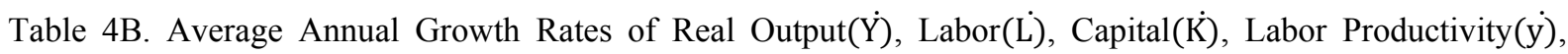
Sources of Economic Growth and Total Factor Productivity (à) for 31 Sub-Saharan Countries for the Period 1995-2008*

\begin{tabular}{|c|c|c|c|c|c|c|c|}
\hline Country & $\dot{\boldsymbol{Y}}$ & $\dot{L}$ & $\dot{\boldsymbol{K}}$ & $C L$ & $C K$ & $\dot{a}$ & $\dot{y}$ \\
\hline Equatorial Guinea & 35.77 & 3.25 & 39.70 & 1.20 & 25.01 & 9.55 & 32.52 \\
\hline Rwanda & 11.27 & 4.80 & 4.02 & 1.78 & 2.53 & 6.96 & 6.47 \\
\hline Angola & 10.38 & 2.45 & 5.34 & 0.91 & 3.36 & 6.11 & 7.93 \\
\hline Zambia & 8.43 & 2.31 & 10.89 & 0.86 & 6.86 & 0.72 & 6.12 \\
\hline Mozambique & 7.97 & 2.68 & 7.43 & 0.99 & 4.68 & 2.30 & 5.29 \\
\hline Ethiopia & 7.34 & 3.58 & 4.78 & 1.32 & 3.01 & 3.00 & 3.76 \\
\hline Botswana & 7.32 & 3.53 & 8.51 & 1.31 & 5.36 & 0.65 & 3.79 \\
\hline Nigeria & 7.02 & 2.66 & 6.09 & 0.98 & 3.84 & 2.20 & 4.36 \\
\hline Uganda & 7.00 & 3.67 & 7.33 & 1.36 & 4.62 & 1.02 & 3.33 \\
\hline Tanzania & 6.77 & 3.09 & 8.86 & 1.14 & 5.58 & 0.05 & 3.69 \\
\hline Chad & 6.72 & 2.46 & 5.17 & 0.91 & 3.26 & 2.55 & 4.26 \\
\hline Burkina Faso & 6.64 & 3.09 & 12.92 & 1.14 & 8.14 & -2.65 & 3.55 \\
\hline Mali & 5.79 & 3.56 & 2.19 & 1.32 & 1.38 & 3.09 & 2.23 \\
\hline Ghana & 5.33 & 3.05 & 3.88 & 1.13 & 2.44 & 1.76 & 2.28 \\
\hline Cape Verde & 5.13 & 2.96 & 5.47 & 1.10 & 3.44 & 0.59 & 2.17 \\
\hline Senegal & 4.59 & 3.02 & 8.85 & 1.12 & 5.58 & -2.11 & 1.56 \\
\hline Mauritius & 4.54 & 1.29 & 3.97 & 0.48 & 2.50 & 1.56 & 3.25 \\
\hline South Africa & 4.14 & 2.47 & 3.95 & 1.51 & 1.54 & 1.09 & 1.67 \\
\hline Malawi & 4.10 & 2.33 & -0.42 & 0.86 & -0.27 & 3.50 & 1.77 \\
\hline Congo Republic & 3.98 & 3.00 & 3.00 & 1.11 & 1.89 & 0.98 & 0.98 \\
\hline Cameroon & 3.66 & 2.98 & 0.76 & 1.10 & 0.48 & 2.07 & 0.67 \\
\hline Kenya & 3.25 & 3.16 & 4.99 & 1.17 & 3.15 & -1.06 & 0.09 \\
\hline Madagascar & 3.22 & 3.22 & 6.22 & 1.19 & 3.92 & -1.89 & 0.00 \\
\hline Burundi & 3.01 & 4.24 & 0.68 & 1.57 & 0.43 & 1.02 & -1.23 \\
\hline Central African Republic & 2.11 & 2.35 & -0.30 & 0.87 & -0.19 & 1.43 & -0.24 \\
\hline Congo Democratic Republic & 2.00 & 3.03 & -0.73 & 1.12 & -0.46 & 1.34 & -1.03 \\
\hline Ivory Coast & 1.95 & 2.75 & 2.52 & 1.02 & 1.59 & -0.66 & -0.80 \\
\hline Sierra Leone & 1.70 & 0.96 & 9.79 & 0.35 & 6.17 & -4.83 & 0.74 \\
\hline Comoros & 1.42 & 4.07 & -3.42 & 1.50 & -2.16 & 2.07 & -2.65 \\
\hline Djibouti & 1.37 & 5.35 & 0.21 & 1.98 & 0.13 & -0.74 & -3.98 \\
\hline Zimbabwe & -5.77 & -0.04 & -2.54 & -0.02 & -1.60 & -4.15 & -5.72 \\
\hline Average & 5.74 & 2.95 & 5.48 & 1.11 & 3.42 & 1.21 & 2.80 \\
\hline
\end{tabular}




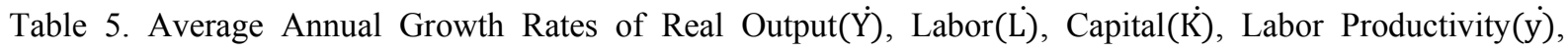
Sources of Economic Growth and Total Factor Productivity (TFP) for 31 Sub-Sahara Countries for the Period 1975-2008*

\begin{tabular}{|c|c|c|c|c|c|c|c|}
\hline Country/Period & $\dot{\boldsymbol{Y}}$ & $\dot{L}$ & $\dot{\boldsymbol{K}}$ & $C L$ & CK & $\dot{a}$ & $\dot{y}$ \\
\hline Angola & 6.45 & 2.29 & 3.52 & 0.85 & 2.21 & 3.39 & 4.16 \\
\hline 1980-1984 & 10.22 & 2.48 & -0.03 & 0.92 & -0.02 & 9.32 & 7.74 \\
\hline 1985-1989 & 4.23 & 1.58 & -3.91 & 0.58 & -2.46 & 6.11 & 2.66 \\
\hline 1990-1994 & -3.09 & 2.52 & 6.54 & 0.93 & 4.12 & -8.14 & -5.61 \\
\hline 1995-1999 & 9.50 & 2.31 & 11.33 & 0.86 & 7.14 & 1.51 & 7.19 \\
\hline 2000-2004 & 4.15 & 2.44 & -0.39 & 0.90 & -0.25 & 3.49 & 1.71 \\
\hline 2005-2008 & 19.26 & 2.63 & 5.02 & 0.97 & 3.16 & 15.12 & 16.63 \\
\hline Botswana & 8.50 & 3.93 & 9.01 & 1.46 & 5.68 & 1.37 & 4.57 \\
\hline 1975-1979 & 9.99 & 4.81 & 10.50 & 1.78 & 6.62 & 1.59 & 5.18 \\
\hline 1980-1984 & 9.99 & 3.67 & 9.43 & 1.36 & 5.94 & 2.69 & 6.32 \\
\hline 1985-1989 & 13.60 & 3.80 & 5.24 & 1.41 & 3.30 & 8.90 & 9.80 \\
\hline 1990-1994 & 3.73 & 4.59 & 12.26 & 1.70 & 7.73 & -5.70 & -0.86 \\
\hline 1995-1999 & 10.26 & 4.35 & 9.09 & 1.61 & 5.73 & 2.92 & 5.91 \\
\hline 2000-2004 & 5.98 & 3.15 & 10.44 & 1.16 & 6.58 & -1.76 & 2.83 \\
\hline 2005-2008 & 5.34 & 2.99 & 5.39 & 1.11 & 3.39 & 0.84 & 2.34 \\
\hline Burkina Faso & 4.18 & 2.88 & 5.19 & 1.07 & 3.27 & -0.16 & 1.30 \\
\hline 1975-1979 & 3.93 & 1.33 & 8.46 & 0.49 & 5.33 & -1.90 & 2.59 \\
\hline $1980-1984$ & 0.18 & 1.99 & 7.08 & 0.74 & 4.46 & -5.02 & -1.81 \\
\hline 1985-1989 & 5.41 & 2.84 & 8.11 & 1.05 & 5.11 & -0.75 & 2.57 \\
\hline 1990-1994 & 2.72 & 3.47 & 5.53 & 1.28 & 3.48 & -2.04 & -0.75 \\
\hline 1995-1999 & 7.62 & 3.30 & 3.50 & 1.22 & 2.21 & 4.20 & 4.33 \\
\hline 2000-2004 & 5.37 & 4.25 & 0.96 & 1.57 & 0.61 & 3.19 & 1.13 \\
\hline 2005-2008 & 4.01 & 3.03 & 2.10 & 1.12 & 1.32 & 1.56 & 0.98 \\
\hline Burundi & 3.12 & 3.06 & 4.82 & 1.13 & 3.04 & -1.05 & 0.05 \\
\hline 1975-1979 & 4.74 & 2.62 & 11.17 & 0.97 & 7.04 & -3.26 & 2.12 \\
\hline 1980-1984 & 2.47 & 3.38 & 10.86 & 1.25 & 6.84 & -5.62 & -0.91 \\
\hline 1985-1989 & 5.53 & 2.05 & 6.37 & 0.76 & 4.02 & 0.75 & 3.48 \\
\hline 1990-1994 & 0.03 & 0.93 & 2.48 & 0.34 & 1.56 & -1.88 & -0.91 \\
\hline 1995-1999 & 3.84 & 2.73 & -3.53 & 1.01 & -2.23 & 5.06 & 1.11 \\
\hline 2000-2004 & 1.81 & 4.86 & -0.21 & 1.80 & -0.13 & 0.14 & -3.05 \\
\hline 2005-2008 & 3.47 & 5.34 & 7.05 & 1.97 & 4.44 & -2.94 & -1.86 \\
\hline Cameroon & 3.64 & 2.82 & 3.79 & 1.04 & 2.39 & 0.21 & 0.82 \\
\hline 1975-1979 & 10.32 & 2.00 & 10.84 & 0.74 & 6.83 & 2.75 & 8.32 \\
\hline 1980-1984 & 6.69 & 2.33 & 9.81 & 0.86 & 6.18 & -0.35 & 4.37 \\
\hline 1985-1989 & 0.69 & 3.13 & 5.13 & 1.16 & 3.23 & -3.70 & -2.44 \\
\hline 1990-1994 & -3.19 & 3.37 & -2.14 & 1.25 & -1.35 & -3.09 & -6.57 \\
\hline 1995-1999 & 3.92 & 3.12 & -3.28 & 1.16 & -2.06 & 4.83 & 0.80 \\
\hline 2000-2004 & 4.05 & 2.97 & 1.99 & 1.10 & 1.25 & 1.70 & 1.08 \\
\hline 2005-2008 & 2.83 & 2.83 & 4.26 & 1.05 & 2.68 & -0.90 & 0.00 \\
\hline Cape Verde & 5.30 & 2.46 & 4.95 & 0.91 & 3.12 & 1.27 & 2.84 \\
\hline 1975-1979 & 2.33 & 1.05 & 4.32 & 0.39 & 2.72 & -0.79 & 1.27 \\
\hline 1980-1984 & 4.29 & 1.77 & 2.02 & 0.65 & 1.27 & 2.36 & 2.52 \\
\hline 1985-1989 & 5.09 & 1.31 & 2.61 & 0.48 & 1.64 & 2.97 & 3.79 \\
\hline 1990-1994 & 4.75 & 2.31 & 4.20 & 0.86 & 2.65 & 1.25 & 2.44 \\
\hline 1995-1999 & 8.01 & 3.59 & 5.80 & 1.33 & 3.65 & 3.03 & 4.42 \\
\hline 2000-2004 & 5.20 & 3.80 & 5.86 & 1.41 & 3.69 & 0.10 & 1.40 \\
\hline 2005-2008 & 7.97 & 3.60 & 11.08 & 1.33 & 6.98 & -0.34 & 4.38 \\
\hline Central African Republic & 1.20 & 2.44 & -0.06 & 0.90 & -0.04 & 0.34 & -1.24 \\
\hline $1975-1979$ & 1.85 & 1.84 & -4.07 & 0.68 & -2.57 & 3.74 & 0.01 \\
\hline $1980-1984$ & 0.03 & 2.68 & -1.68 & 0.99 & -1.06 & 0.10 & -2.65 \\
\hline 1985-1989 & 1.28 & 2.35 & 3.43 & 0.87 & 2.16 & -1.75 & -1.07 \\
\hline 1990-1994 & -0.87 & 3.19 & 2.77 & 1.18 & 1.75 & -3.80 & -4.06 \\
\hline
\end{tabular}




\begin{tabular}{|c|c|c|c|c|c|c|c|}
\hline 1995-1999 & 2.29 & 2.40 & -0.05 & 0.89 & -0.03 & 1.43 & -0.11 \\
\hline 2000-2004 & -0.89 & 2.32 & -2.75 & 0.86 & -1.73 & -0.01 & -3.21 \\
\hline 2005-2008 & 5.63 & 2.32 & 2.46 & 0.86 & 1.55 & 3.22 & 3.31 \\
\hline Chad & 4.30 & 2.44 & 7.63 & 0.90 & 4.81 & -1.41 & 1.86 \\
\hline 1975-1979 & -3.01 & 1.88 & 7.19 & 0.70 & 4.53 & -8.24 & -4.90 \\
\hline 1980-1984 & 3.62 & 1.51 & 1.33 & 0.56 & 0.84 & 2.22 & 2.11 \\
\hline 1985-1989 & 6.98 & 2.04 & 3.32 & 0.76 & 2.09 & 4.14 & 4.94 \\
\hline 1990-1994 & 3.07 & 2.52 & 3.90 & 0.93 & 2.46 & -0.32 & 0.55 \\
\hline 1995-1999 & 2.27 & 3.43 & 5.49 & 1.27 & 3.46 & -2.46 & -1.17 \\
\hline 2000-2004 & 14.96 & 2.94 & 24.18 & 1.09 & 15.23 & -1.36 & 12.02 \\
\hline 2005-2008 & 1.70 & 2.86 & 8.14 & 1.06 & 5.13 & -4.49 & -1.16 \\
\hline Comoros & 2.08 & 3.57 & $\mathbf{0 . 0 7}$ & 1.32 & 0.04 & 0.71 & -1.50 \\
\hline 1975-1979 & 4.63 & 3.80 & 5.82 & 1.41 & 3.66 & -0.44 & 0.83 \\
\hline 1980-1984 & 5.68 & 1.91 & 5.72 & 0.71 & 3.60 & 1.37 & 3.77 \\
\hline 1985-1989 & -0.22 & 3.14 & 0.18 & 1.16 & 0.11 & -1.49 & -3.36 \\
\hline 1990-1994 & 0.08 & 4.08 & -1.65 & 1.51 & -1.04 & -0.39 & -4.00 \\
\hline 1995-1999 & 0.89 & 4.59 & -3.07 & 1.70 & -1.93 & 1.12 & -3.70 \\
\hline 2000-2004 & 1.22 & 4.06 & -4.56 & 1.50 & -2.87 & 2.59 & -2.83 \\
\hline 2005-2008 & 2.32 & 3.42 & -2.44 & 1.27 & -1.54 & 2.59 & -1.10 \\
\hline Congo Democratic Rep. & -0.44 & 2.87 & 0.26 & 1.06 & 0.16 & -1.67 & -3.32 \\
\hline 1975-1979 & -3.13 & 2.41 & 2.53 & 0.89 & 1.59 & -5.61 & -5.54 \\
\hline $1980-1984$ & 3.54 & 2.36 & 0.89 & 0.87 & 0.56 & 2.11 & 1.18 \\
\hline 1985-1989 & 0.72 & 2.80 & 0.00 & 1.04 & 0.00 & -0.32 & -2.09 \\
\hline 1990-1994 & -9.76 & 3.47 & 0.37 & 1.29 & 0.23 & -11.27 & -13.23 \\
\hline 1995-1999 & -9.71 & 2.61 & -3.47 & 0.97 & -2.19 & -8.49 & -12.32 \\
\hline 2000-2004 & 10.37 & 3.19 & -2.50 & 1.18 & -1.58 & 10.76 & 7.18 \\
\hline 2005-2008 & 6.19 & 3.37 & 4.93 & 1.25 & 3.10 & 1.84 & 2.82 \\
\hline Congo Republic & 3.97 & 3.11 & 5.36 & 1.15 & 3.38 & -0.56 & 0.86 \\
\hline 1975-1979 & 1.83 & 2.82 & 7.29 & 1.04 & 4.59 & -3.80 & -0.99 \\
\hline 1980-1984 & 13.51 & 3.55 & 10.30 & 1.31 & 6.49 & 5.71 & 9.96 \\
\hline 1985-1989 & 0.47 & 2.08 & 5.57 & 0.77 & 3.51 & -3.81 & -1.61 \\
\hline 1990-1994 & 0.01 & 4.29 & 5.39 & 1.59 & 3.39 & -4.97 & -4.28 \\
\hline 1995-1999 & 5.94 & 2.90 & 1.21 & 1.07 & 0.76 & 4.10 & 3.04 \\
\hline 2000-2004 & 1.38 & 3.02 & 2.60 & 1.12 & 1.64 & -1.37 & -1.64 \\
\hline 2005-2008 & 4.62 & 3.09 & 5.18 & 1.14 & 3.26 & 0.22 & 1.53 \\
\hline Djibouti & 1.49 & 5.90 & 3.73 & 2.18 & 2.35 & -3.04 & -4.41 \\
\hline 1980-1984 & 4.16 & -8.04 & 13.75 & -2.98 & 8.66 & -1.53 & 12.20 \\
\hline 1985-1989 & -0.93 & 4.62 & 3.50 & 1.71 & 2.20 & -4.85 & -5.55 \\
\hline 1990-1994 & 3.71 & 11.50 & 11.81 & 4.25 & 7.44 & -7.98 & -7.79 \\
\hline 1995-1999 & 0.07 & -2.63 & 1.34 & -0.97 & 0.84 & 0.20 & 2.70 \\
\hline 2000-2004 & 2.02 & 12.31 & -4.49 & 4.56 & -2.83 & 0.29 & -10.30 \\
\hline 2005-2008 & 2.19 & 6.62 & 4.67 & 2.45 & 2.94 & -3.20 & -4.43 \\
\hline Equatorial Guinea & 15.47 & 3.01 & 19.96 & 1.11 & 12.57 & 1.78 & 12.46 \\
\hline 1975-1979 & -3.26 & -2.32 & 0.52 & -0.86 & 0.33 & -2.73 & -0.94 \\
\hline 1980-1984 & 2.97 & 10.97 & -0.51 & 4.06 & -0.32 & -0.77 & -8.00 \\
\hline 1985-1989 & 3.25 & 2.22 & 0.85 & 0.82 & 0.54 & 1.90 & 1.04 \\
\hline 1990-1994 & 2.07 & 0.49 & 23.69 & 0.18 & 14.92 & -13.04 & 1.58 \\
\hline 1995-1999 & 58.89 & 2.11 & 70.60 & 0.78 & 44.48 & 13.63 & 56.78 \\
\hline 2000-2004 & 30.28 & 3.95 & 26.78 & 1.46 & 16.87 & 11.96 & 26.34 \\
\hline 2005-2008 & 13.72 & 3.81 & 17.23 & 1.41 & 10.85 & 1.46 & 9.91 \\
\hline Ethiopia & 4.06 & 2.93 & 3.11 & 1.09 & 1.96 & 1.01 & 1.12 \\
\hline 1975-1979 & 0.49 & 1.90 & -1.08 & 0.70 & -0.68 & 0.47 & -1.41 \\
\hline $1980-1984$ & 2.57 & 3.16 & 3.20 & 1.17 & 2.02 & -0.61 & -0.58 \\
\hline 1985-1989 & 2.77 & 2.34 & 5.09 & 0.87 & 3.20 & -1.30 & 0.43 \\
\hline 1990-1994 & 1.21 & 2.53 & 0.57 & 0.94 & 0.36 & -0.09 & -1.32 \\
\hline 1995-1999 & 7.14 & 2.72 & 0.30 & 1.01 & 0.19 & 5.94 & 4.42 \\
\hline
\end{tabular}




\begin{tabular}{|c|c|c|c|c|c|c|c|}
\hline 2000-2004 & 3.86 & 4.22 & 4.05 & 1.56 & 2.55 & -0.25 & -0.36 \\
\hline 2005-2008 & 11.92 & 3.85 & 11.30 & 1.42 & 7.12 & 3.38 & 8.07 \\
\hline Ghana & 3.36 & 3.09 & 1.64 & 1.14 & 1.03 & 1.18 & 0.27 \\
\hline 1975-1979 & -0.13 & 1.90 & -1.74 & 0.70 & -1.09 & 0.26 & -2.03 \\
\hline 1980-1984 & 0.80 & 3.68 & -3.57 & 1.36 & -2.25 & 1.69 & -2.88 \\
\hline 1985-1989 & 5.11 & 3.50 & -1.59 & 1.29 & -1.00 & 4.82 & 1.61 \\
\hline 1990-1994 & 2.67 & 3.62 & 2.73 & 1.34 & 1.72 & -0.39 & -0.95 \\
\hline 1995-1999 & 1.80 & 3.33 & 5.14 & 1.23 & 3.24 & -2.67 & -1.53 \\
\hline 2000-2004 & 6.96 & 2.91 & 2.92 & 1.08 & 1.84 & 4.04 & 4.05 \\
\hline 2005-2008 & 7.00 & 2.56 & 9.04 & 0.95 & 5.70 & 0.36 & 4.45 \\
\hline Ivory Coast & 2.98 & 3.48 & 1.42 & 1.29 & 0.90 & 0.80 & -0.50 \\
\hline 1975-1979 & 7.74 & 3.81 & 11.23 & 1.41 & 7.08 & -0.74 & 3.93 \\
\hline $1980-1984$ & 1.42 & 3.88 & 1.36 & 1.44 & 0.85 & -0.87 & -2.47 \\
\hline 1985-1989 & 5.95 & 3.93 & -4.55 & 1.45 & -2.86 & 7.36 & 2.02 \\
\hline 1990-1994 & -0.28 & 4.34 & -5.44 & 1.60 & -3.42 & 1.54 & -4.61 \\
\hline 1995-1999 & 5.04 & 3.18 & 3.61 & 1.18 & 2.27 & 1.59 & 1.86 \\
\hline 2000-2004 & -0.90 & 2.55 & 1.52 & 0.94 & 0.96 & -2.80 & -3.45 \\
\hline 2005-2008 & 1.63 & 2.45 & 2.42 & 0.91 & 1.52 & -0.79 & -0.82 \\
\hline Kenya & 3.52 & 3.57 & 3.26 & 1.32 & 2.05 & 0.14 & -0.06 \\
\hline 1975-1979 & 4.37 & 3.67 & 4.77 & 1.36 & 3.01 & 0.00 & 0.70 \\
\hline 1980-1984 & 2.59 & 3.94 & 2.10 & 1.46 & 1.32 & -0.18 & -1.34 \\
\hline 1985-1989 & 5.97 & 3.84 & 1.55 & 1.42 & 0.98 & 3.57 & 2.13 \\
\hline 1990-1994 & 1.89 & 4.02 & -0.24 & 1.49 & -0.15 & 0.55 & -2.14 \\
\hline 1995-1999 & 3.25 & 3.17 & 3.59 & 1.17 & 2.26 & -0.19 & 0.08 \\
\hline 2000-2004 & 2.62 & 3.32 & 3.79 & 1.23 & 2.39 & -1.00 & -0.70 \\
\hline 2005-2008 & 4.05 & 2.94 & 8.24 & 1.09 & 5.19 & -2.24 & 1.10 \\
\hline Madagascar & 2.61 & 3.11 & 2.36 & 1.15 & 1.49 & -0.03 & -0.50 \\
\hline 1975-1979 & -0.82 & 2.48 & 1.15 & 0.92 & 0.73 & -2.46 & -3.30 \\
\hline 1980-1984 & 1.71 & 3.22 & -1.06 & 1.19 & -0.67 & 1.19 & -1.51 \\
\hline 1985-1989 & 8.28 & 3.19 & -1.02 & 1.18 & -0.64 & 7.74 & 5.09 \\
\hline 1990-1994 & -0.45 & 3.25 & -0.43 & 1.20 & -0.27 & -1.38 & -3.70 \\
\hline 1995-1999 & 2.89 & 2.92 & 1.87 & 1.08 & 1.18 & 0.63 & -0.03 \\
\hline 2000-2004 & 0.94 & 3.29 & 5.04 & 1.22 & 3.18 & -3.45 & -2.35 \\
\hline 2005-2008 & 6.48 & 3.51 & 13.14 & 1.30 & 8.28 & -3.10 & 2.96 \\
\hline Malawi & 2.69 & 2.74 & 0.65 & 1.02 & 0.41 & 1.26 & -0.06 \\
\hline 1975-1979 & 6.79 & 3.26 & 10.68 & 1.20 & 6.73 & -1.15 & 3.53 \\
\hline 1980-1984 & -1.69 & 2.46 & 0.26 & 0.91 & 0.17 & -2.77 & -4.16 \\
\hline 1985-1989 & 1.95 & 3.29 & -2.94 & 1.22 & -1.85 & 2.59 & -1.34 \\
\hline 1990-1994 & -0.25 & 3.13 & -2.41 & 1.16 & -1.52 & 0.11 & -3.38 \\
\hline 1995-1999 & 5.43 & 1.70 & -1.75 & 0.63 & -1.10 & 5.90 & 3.73 \\
\hline 2000-2004 & 1.66 & 2.76 & -0.69 & 1.02 & -0.43 & 1.07 & -1.10 \\
\hline 2005-2008 & 5.48 & 2.59 & 1.57 & 0.96 & 0.99 & 3.54 & 2.89 \\
\hline Mali & 5.02 & 2.12 & 4.50 & 0.78 & 2.84 & 1.40 & 2.90 \\
\hline 1975-1979 & 9.62 & 1.57 & 7.95 & 0.58 & 5.01 & 4.03 & 8.06 \\
\hline 1980-1984 & -0.30 & 1.27 & 3.00 & 0.47 & 1.89 & -2.66 & -1.57 \\
\hline 1985-1989 & 6.93 & 1.36 & 5.13 & 0.50 & 3.23 & 3.20 & 5.57 \\
\hline 1990-1994 & 2.94 & 1.67 & 3.69 & 0.62 & 2.33 & 0.00 & 1.27 \\
\hline 1995-1999 & 5.77 & 2.03 & 3.81 & 0.75 & 2.40 & 2.62 & 3.74 \\
\hline 2000-2004 & 4.46 & 4.17 & 2.15 & 1.54 & 1.35 & 1.57 & 0.29 \\
\hline 2005-2008 & 5.86 & 2.91 & 6.12 & 1.08 & 3.86 & 0.92 & 2.95 \\
\hline Mauritius & 5.38 & 1.99 & 5.21 & 0.74 & 3.28 & 1.36 & 3.39 \\
\hline 1975-1979 & 10.08 & 3.17 & 11.12 & 1.17 & 7.00 & 1.90 & 6.90 \\
\hline 1980-1984 & 0.65 & 2.83 & 1.39 & 1.05 & 0.88 & -1.28 & -2.19 \\
\hline 1985-1989 & 7.71 & 2.10 & 5.52 & 0.78 & 3.48 & 3.46 & 5.61 \\
\hline 1990-1994 & 5.41 & 1.80 & 6.26 & 0.67 & 3.94 & 0.80 & 3.61 \\
\hline 1995-1999 & 4.75 & 1.63 & 6.03 & 0.60 & 3.80 & 0.35 & 3.12 \\
\hline
\end{tabular}




\begin{tabular}{|c|c|c|c|c|c|c|c|}
\hline 2000-2004 & 5.04 & 0.71 & 4.19 & 0.26 & 2.64 & 2.14 & 4.34 \\
\hline 2005-2008 & 3.65 & 1.61 & 1.13 & 0.59 & 0.71 & 2.35 & 2.04 \\
\hline Mozambique & 3.74 & 2.08 & 4.68 & 0.77 & 2.95 & 0.02 & 1.66 \\
\hline 1975-1979 & 2.25 & 2.40 & 6.53 & 0.89 & 4.11 & -2.75 & -0.16 \\
\hline 1980-1984 & -1.42 & 1.65 & 1.19 & 0.61 & 0.75 & -2.78 & -3.07 \\
\hline 1985-1989 & 1.05 & -1.74 & 0.26 & -0.64 & 0.17 & 1.53 & 2.79 \\
\hline 1990-1994 & 1.22 & 4.32 & 3.06 & 1.60 & 1.93 & -2.31 & -3.10 \\
\hline 1995-1999 & 7.15 & 3.94 & 9.82 & 1.46 & 6.18 & -0.49 & 3.22 \\
\hline 2000-2004 & 8.98 & 2.06 & 7.13 & 0.76 & 4.49 & 3.73 & 6.93 \\
\hline 2005-2008 & 7.73 & 1.90 & 4.81 & 0.70 & 3.03 & 4.00 & 5.83 \\
\hline Nigeria & 2.92 & 2.55 & 3.15 & 0.94 & 1.99 & -0.01 & 0.37 \\
\hline 1975-1979 & -1.41 & 2.71 & 14.17 & 1.00 & 8.93 & -11.34 & -4.12 \\
\hline $1980-1984$ & -1.42 & 2.35 & 3.06 & 0.87 & 1.93 & -4.22 & -3.78 \\
\hline 1985-1989 & 0.30 & 2.12 & -6.02 & 0.78 & -3.79 & 3.30 & -1.82 \\
\hline 1990-1994 & 2.75 & 2.75 & -6.82 & 1.02 & -4.30 & 6.03 & 0.00 \\
\hline 1995-1999 & 2.60 & 2.93 & -3.92 & 1.08 & -2.47 & 3.98 & -0.33 \\
\hline 2000-2004 & 9.85 & 2.60 & -0.75 & 0.96 & -0.47 & 9.36 & 7.25 \\
\hline 2005-2008 & 9.00 & 2.38 & 27.16 & 0.88 & 17.11 & -8.99 & 6.62 \\
\hline Rwanda & 4.94 & 2.99 & 5.92 & 1.11 & 3.73 & 0.11 & 1.95 \\
\hline 1975-1979 & 4.90 & 2.97 & 12.38 & 1.10 & 7.80 & -3.99 & 1.93 \\
\hline 1980-1984 & 3.23 & 2.80 & 11.19 & 1.04 & 7.05 & -4.86 & 0.43 \\
\hline 1985-1989 & 2.33 & 2.67 & 7.30 & 0.99 & 4.60 & -3.25 & -0.34 \\
\hline 1990-1994 & -8.41 & -1.54 & -1.89 & -0.57 & -1.19 & -6.65 & -6.87 \\
\hline 1995-1999 & 17.59 & 6.88 & -3.03 & 2.54 & -1.91 & 16.95 & 10.71 \\
\hline 2000-2004 & 5.44 & 3.93 & 3.16 & 1.46 & 1.99 & 1.99 & 1.50 \\
\hline 2005-2008 & 10.66 & 3.29 & 13.90 & 1.22 & 8.75 & 0.69 & 7.37 \\
\hline Senegal & 3.46 & 2.71 & $\mathbf{5 . 5 7}$ & 1.00 & 3.51 & -1.05 & 0.75 \\
\hline 1975-1979 & 3.80 & 2.48 & 3.39 & 0.92 & 2.14 & 0.75 & 1.32 \\
\hline 1980-1984 & 1.88 & 2.87 & 3.08 & 1.06 & 1.94 & -1.12 & -0.99 \\
\hline 1985-1989 & 3.25 & 3.30 & 2.99 & 1.22 & 1.88 & 0.15 & -0.05 \\
\hline 1990-1994 & 1.76 & 1.33 & 3.66 & 0.49 & 2.31 & -1.04 & 0.42 \\
\hline 1995-1999 & 5.13 & 2.80 & 8.40 & 1.04 & 5.29 & -1.20 & 2.33 \\
\hline 2000-2004 & 4.32 & 3.09 & 9.33 & 1.14 & 5.88 & -2.71 & 1.23 \\
\hline 2005-2008 & 4.25 & 3.22 & 8.81 & 1.19 & 5.55 & -2.49 & 1.04 \\
\hline Sierra Leone & 1.41 & 1.36 & 4.98 & 0.50 & 3.14 & -2.23 & 0.05 \\
\hline 1975-1979 & 1.99 & 1.52 & 3.74 & 0.56 & 2.36 & -0.93 & 0.47 \\
\hline 1980-1984 & 2.91 & 1.59 & 2.86 & 0.59 & 1.80 & 0.52 & 1.32 \\
\hline 1985-1989 & 2.46 & 2.13 & 0.92 & 0.79 & 0.58 & 1.09 & 0.33 \\
\hline 1990-1994 & -2.54 & 1.31 & -1.10 & 0.48 & -0.69 & -2.34 & -3.85 \\
\hline 1995-1999 & -12.41 & -2.50 & -6.98 & -0.92 & -4.40 & -7.09 & -9.91 \\
\hline 2000-2004 & 12.07 & 3.73 & -7.39 & 1.38 & -4.65 & 15.34 & 8.34 \\
\hline 2005-2008 & 6.37 & 1.82 & 52.24 & 0.67 & 32.91 & -27.21 & 4.55 \\
\hline South Africa & 3.09 & 3.01 & 2.46 & 1.84 & 0.96 & 0.29 & 0.07 \\
\hline 1975-1979 & 3.16 & 2.63 & 4.21 & 1.60 & 1.64 & -0.09 & 0.53 \\
\hline 1980-1984 & 3.86 & 3.71 & 4.23 & 2.26 & 1.65 & -0.05 & 0.15 \\
\hline 1985-1989 & 1.40 & 3.37 & -1.37 & 2.06 & -0.53 & -0.12 & -1.97 \\
\hline 1990-1994 & 0.98 & 3.86 & -1.41 & 2.36 & -0.55 & -0.82 & -2.88 \\
\hline 1995-1999 & 3.06 & 2.85 & 1.66 & 1.74 & 0.65 & 0.67 & 0.21 \\
\hline 2000-2004 & 3.82 & 2.22 & 3.71 & 1.35 & 1.45 & 1.02 & 1.60 \\
\hline 2005-2008 & 5.89 & 2.32 & 7.11 & 1.42 & 2.77 & 1.70 & 3.57 \\
\hline Tanzania & 4.63 & 2.81 & 4.82 & 1.04 & 3.04 & 0.55 & 1.82 \\
\hline 1975-1979 & 3.49 & 2.50 & 6.65 & 0.93 & 4.19 & -1.62 & 0.99 \\
\hline 1980-1984 & 1.08 & 2.93 & 0.30 & 1.08 & 0.19 & -0.19 & -1.85 \\
\hline 1985-1989 & 4.60 & 3.22 & 4.29 & 1.19 & 2.71 & 0.70 & 1.38 \\
\hline 1990-1994 & 3.48 & 3.55 & 7.06 & 1.31 & 4.45 & -2.28 & -0.07 \\
\hline 1995-1999 & 5.00 & 2.84 & 2.15 & 1.05 & 1.36 & 2.59 & 2.16 \\
\hline
\end{tabular}




\begin{tabular}{|c|c|c|c|c|c|c|c|}
\hline 2000-2004 & 5.30 & 2.43 & 3.93 & 0.90 & 2.47 & 1.93 & 2.87 \\
\hline 2005-2008 & 10.64 & 2.01 & 10.49 & 0.75 & 6.61 & 3.28 & 8.63 \\
\hline Uganda & 4.53 & 3.02 & 5.00 & 1.12 & 3.15 & 0.27 & 1.51 \\
\hline 1975-1979 & -3.36 & 2.31 & -5.02 & 0.86 & -3.16 & -1.05 & -5.67 \\
\hline 1980-1984 & 1.97 & 2.64 & -0.34 & 0.98 & -0.21 & 1.21 & -0.67 \\
\hline 1985-1989 & 3.41 & 3.78 & 6.81 & 1.40 & 4.29 & -2.28 & -0.37 \\
\hline 1990-1994 & 9.84 & 3.19 & 7.70 & 1.18 & 4.85 & 3.80 & 6.64 \\
\hline 1995-1999 & 5.89 & 2.50 & 9.32 & 0.92 & 5.87 & -0.91 & 3.39 \\
\hline 2000-2004 & 5.22 & 3.18 & 6.87 & 1.18 & 4.33 & -0.29 & 2.03 \\
\hline 2005-2008 & 9.82 & 3.71 & 10.78 & 1.37 & 6.79 & 1.66 & 6.12 \\
\hline Zambia & 2.86 & 2.91 & 1.45 & 1.08 & 0.91 & 0.87 & -0.05 \\
\hline 1975-1979 & -3.46 & 2.46 & -0.33 & 0.91 & -0.21 & -4.16 & -5.91 \\
\hline 1980-1984 & -1.09 & 3.75 & -5.60 & 1.39 & -3.53 & 1.05 & -4.84 \\
\hline 1985-1989 & 2.89 & 3.80 & -9.55 & 1.40 & -6.02 & 7.51 & -0.90 \\
\hline 1990-1994 & -2.47 & 3.33 & -5.15 & 1.23 & -3.24 & -0.46 & -5.80 \\
\hline 1995-1999 & 0.33 & 2.35 & 0.50 & 0.87 & 0.31 & -0.86 & -2.03 \\
\hline 2000-2004 & 14.51 & 2.29 & 12.61 & 0.85 & 7.95 & 5.72 & 12.23 \\
\hline 2005-2008 & 10.96 & 2.30 & 21.71 & 0.85 & 13.68 & -3.57 & 8.66 \\
\hline Zimbabwe & -0.65 & 1.98 & 0.45 & 0.73 & 0.28 & -1.66 & -2.62 \\
\hline 1975-1979 & 0.17 & 1.81 & 1.02 & 0.67 & 0.64 & -1.14 & -1.64 \\
\hline 1980-1984 & 3.42 & 3.91 & 2.33 & 1.45 & 1.47 & 0.50 & -0.49 \\
\hline 1985-1989 & 6.03 & 4.57 & 0.58 & 1.69 & 0.37 & 3.97 & 1.46 \\
\hline 1990-1994 & 2.45 & 3.20 & 6.45 & 1.18 & 4.07 & -2.80 & -0.75 \\
\hline 1995-1999 & 3.65 & 1.19 & 2.60 & 0.44 & 1.64 & 1.57 & 2.46 \\
\hline 2000-2004 & -13.41 & -0.21 & -2.96 & -0.08 & -1.86 & -11.47 & -13.20 \\
\hline 2005-2008 & -7.98 & -1.37 & -8.45 & -0.51 & -5.32 & -2.15 & -6.61 \\
\hline Average & 3.74 & 2.83 & 4.06 & 1.07 & 2.54 & 0.12 & 0.90 \\
\hline
\end{tabular}

*Angola and Djibouti data are from 1984-2008. 